UDK 343.343.6(436)(439)

Biblid 0543-3657, 72 (2021)

God. LXXII, br. 1183, str. 107-129

pregledni rad

Primljen: 27.2.2021.

Prihvaćen: 25.7.2021.

doi: https://doi.org/10.18485/iipe_mp.2021.72.1183.6

Zoran OBRADOVIĆ

Aleksandar ŽIVANOVIĆ ${ }^{2}$

\title{
Migrantska kriza, ilegalne migracije i trgovina ljudima kao bezbednosni problem - studija slučaja Austrije i Mađarske
}

\section{SAŽETAK}

Migracije podstaknute ratom i stradanjem, delovanjem radikalnih islamista i formiranjem Islamske države na teritoriji nekoliko bliskoistočnih država primorale su evropske države da planski i sistematski deluju protiv najezde migranata u dužem vremenskom periodu, trošeći pritom svoje resurse i prekomerno upošljavajući svoje policijske, vojne i civilne kapacitete. Savremene ilegalne migracije pokušaćamo da sagledamo kroz temu: „Ilegalne migracije i bezbednosni odgovori - studija slučaja na primeru Austrije i Mađarske". Analizirali smo rad i rezultate sistema zemalja jugoistočne Evrope za borbu protiv trgovine i šverca ljudi, u Austriji kao i u Mađarskoj, i ovde mislimo na vladine i nevladine organizacije i njihovu ulogu u tom sistemu, kako bismo otkrili koji kapaciteti još uvek nisu razvijeni i o kakvim nedostacima se zapravo radi.

Ključne reči: Ilegalne migracije, trgovina ljudima, Evropa, Austrija, Mađarska.

\footnotetext{
${ }^{1}$ Autor je zaposlen u Ministarstvu odbrane Republike Srbije, e-pošta: obradoviczoran933@ gmail.com

${ }^{2}$ Autor je student master akademskih studija na Fakultetu političkih nauka Univerziteta $\mathrm{u}$ Beogradu, e-pošta: acamzivanovic@gmail.com
} 


\section{Ilegalne migracije i trgovina ljudima (rezultati istraživanja)}

Migracije kao pojam uključuju premeštanje stanovništva, kako u okviru jedne države tako i premeštanje stanovništva iz jedne $u$ drugu državu. ${ }^{3}$ Trgovina ljudima i šverc ilegalnih migranata su povezani i slični, ali mogu zbuniti posmatrače koji nemaju iskustva u tom polju. Po svojoj prirodi, šverc je uvek međunarodni a trgovina ljudima ne mora da sadrži međunarodne elemente. ${ }^{4}$ Trgovina ljudima se može odigravati na malom prostoru unutar državnih granica. Prekogranične migracije bez dokumenata ne moraju biti prinudne i iskorišćavajuće, dok su prinuda i eksploatacija osnovni elementi definicije trgovine ljudima. Razlika u terminima je napravljena zbog svrhe prelaska granice. Protokol UN protiv šverca migranata kopnenim, pomorskim i vazdušnim putem definiše šverc kao „Nabavku, da bi se stekla, direktno ili indirektno, finansijska ili druga materijalna korist od ilegalnog ulaska lica u državu čiji to lice nije državljanin i nema stalni boravak tamo." Ovaj protokol naglašava međusobni finansijski dogovor između švercera i migranta zbog ilegalnog prebacivanja lica preko državne granice, a glavni deo definicije je čin šverca. „Protokol Ujedinjenih nacija za sprečavanje, suzbijanje i kažnjavanje trgovine ljudima, posebno ženama i decom" definiše se kao čin trgovine ljudima kad postoji ilegalno prebacivanje protiv volje lica, korišćenjem prinude, mita, sile ili prevare. ${ }^{5}$ Međutim, iako su ove dve vrste organizovanog kriminala različite po definicijama i sadržaju, one mogu delovati zajedno. Švercovani migranti su veoma podložni eksploataciji zbog njihovog neregulisanog statusa, zbog čega su izloženi zloupotrebi i iskorišćavanju. Ako postoji situacija u kojoj su migranti iskorišćeni, čin šverca će prerasti u čin trgovine. Eksploatacija se može desiti u bilo kom trenutku transporta ili na samoj destinaciji. Čak i ako se migrant oslobodi švercera na samoj destinaciji, ilegalni migranti su i dalje podložni i pod rizikom eksploatacije i zloupotrebe. ${ }^{6}$ Još uvek postoji potražnja za jeftinom radnom snagom i seksualnim uslugama. Uobičajeni faktori koji teraju migrante na to, kao što su siromaštvo ili neravnopravan status, doprinose ranjivosti migranata. U Republici Srbiji i drugim zemljama koje su se suočile sa masovnim prilivom migranata i izbeglica tokom 2014, 2015. i delom 2016. godine, ključne izazove je predstavljalo pružanje i zadovoljavanje osnovnih neposrednih potreba migranata i izbeglica. Za

\footnotetext{
${ }^{3}$ Dragan Petrović, Rajko Bukvić, Evropa i Migrantsko pitanje 2014-2020, Institut za međunarodnu politiku i privredu, 2020, p. 19.

${ }^{4}$ Veerendra Mishra, Combating Human Trafficking: Gaps in Policy and Law, Sage publications, New York, 2015, pp. 62-63.

${ }^{5}$ United Nations Protocol against Smuggling of Migrants by Land, See and Air, march 2000.

${ }^{6}$ Mishra Veerendra, Combating Human Trafficking: Gaps in Policy and Law, Sage publications,

108 New York, 2015, pp. 79-80.
} 
vreme migrantske krize, veliki broj migranata je prošao preko teritorije Srbije gde su se zadržavali kratko, od nekoliko sati do jedne nedelje.

Dijagram 1: Broj ilegalnih migranata registrovanih u Republici Srbiji 2014. i 2015. godine

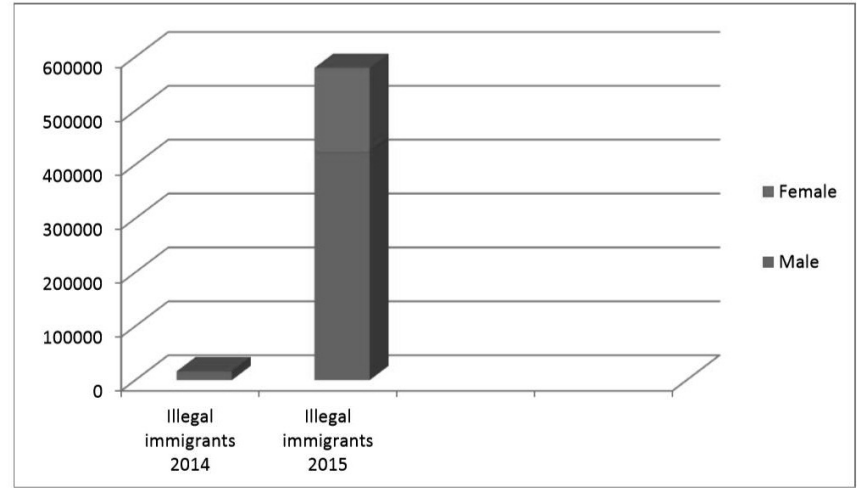

Izvor: razgovor sa istraživačima NVO „Grupa 484".7

Na Dijagramu 1 može se videti trend porasta broja ilegalnih migranata registrovanih u Republici Srbiji za vreme migrantske krize 2014. i 2015. godine. Republika Srbija je 2014. godine zabeležila priliv od 16.500 ilegalnih migranata sa namerom da traže azil, od kojih je 14.361 bilo muškaraca, a 1.869 žena, koje su posebno osetljive na trgovinu. Broj migranata koji je nameravao da traži azil 2015. godine se povećao za više od 35 puta, sa ukupnim brojem od 579.518 ilegalnih migranata od kojih je 422.322 bilo muškaraca i 157.186 žena. Nepostojanje pregleda migrantskog priliva dovelo je do nepoštovanja prava i nepostojanja zaštitnih mehanizama koji treba da postoje za izbeglice i migrante. Većina uvedenih pravila je rezultat odluka na političkom nivou. To je dovelo do osećaja pravne nesigurnosti migranata i posledično do nepoverenja $u$ državne organe. Zbog toga su migranti pokušavali da izbegnu zvanične granične prelaze i registrovanje. Zbog izbegavanja registracije u prihvatnim centrima i svakog kontakta sa vlastima, iskomplikovalo se identifikovanje mogućih žrtava trgovine ljudima, pružanje usluga i neophodne zaštite za njih.

${ }^{7}$ Istraživači nevladine organizacije „Grupa 484" pružili su date podatke tokom jula 2017. godine 
Dijagram 2: Broj lica koji su ilegalno prešli državnu granicu Republike Srbije 2014. i 2015. godine

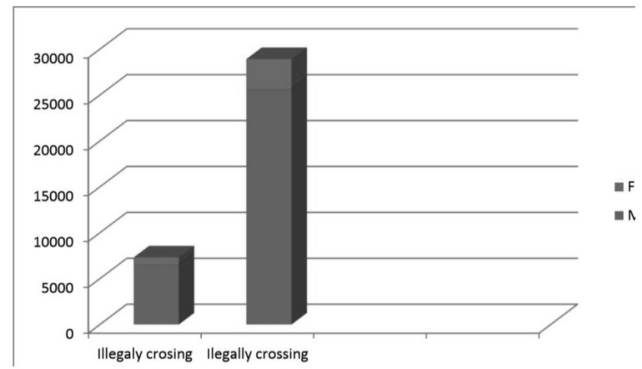

Izvor: razgovor sa istraživačima NVO „Grupa 484".

Na Dijagramu 2 predstavljen je trend pojačanih aktivnosti migranata na ilegalnom prelasku državne granice Republike Srbije. Tokom 2014. godine otkriveno je ukupno 7.303 migranta, od kojih 6.492 muškaraca i 811 žena, da prelaze granicu van zvaničnih prelaznih punktova izbegavajući registrovanje i kontakt sa srpskim vlastima. U 2015. godini taj broj se povećao skoro četiri puta i iznosio je 28.913. Ukupno 25.619 muškaraca i 3.294 žene su otkrivene da ilegalno prelaze granicu Republike Srbije. Početkom 2016. godine, kad je došlo do promene političkog stava o ilegalnim migracijama i zbeglicama, promenio se i broj registrovanih migranata. Ključna razlika je to što su migranti, bez obzira na jasnu nameru putovanja u zapadnu Evropu, konkretno u Nemačku, duže ostajali na teritoriji Republike Srbije pa su se tako smanjile i prilike da oni bezbedno prelaze granice. Mere vlade na boljoj kontroli državnih granica dovele su do povećanja šverca migranata.

Dijagram 3: Identifikovane žrtve trgovine ljudima u Republici Srbiji 2014. i 2015. u poređenju sa žrtvama trgovine ljudima kod migrantske populacije 2014. i 2015. godine

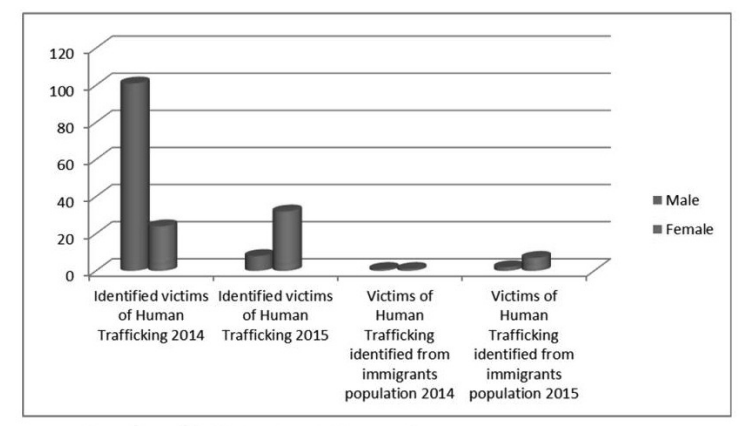

110 Izvor: razgovor sa istraživačima NVO „Grupa 484”. 
Na Dijagramu 3 uočava se trend povećanja identifikovanja žrtava trgovine ljudima kod migrantske populacije 2015. u odnosu na 2014. godinu. Međutim, vladine akcije za istraživanje trgovine ljudima opale su u 2014. i 2015. godini. To se može objasniti prebacivanjem sredstava bezbednosnih službi sa internih istraga na istrage graničnih i prekograničnih aktivnosti i istraživanje trgovine ljudima među migrantima. Srpske vlasti su 2014. godine otkrile 125 žrtava trgovine ljudima, među kojima je bio 101 muškarac i 24 žene. U tom periodu identifikovan je samo jedan muškarac i jedna žena kao žrtve trgovine među migrantima. U 2015. godini identifikovano je ukupno 40 žrtava trgovine ljudima, od kojih 8 muškaraca i 32 žene, a u istom periodu devet žrtava je identifikovano kod migrantske populacije, dva muškarca i sedam žena. To je mali broj identifikovanih žrtava, a u razgovoru sa istraživačem NVO "Grupa 484 " rečeno je da je to zbog preraspodele sredstava bezbednosnih službi sa slučajeva trgovine ljudima na zaštitu granice i suzbijanje nelegalne migracije. Takođe se može primetiti povećan broj identifikovanih ženskih žrtava, što se može smatrati zaštitom posebno ranjivih kategorija. Ali u poređenju sa brojem registrovanih ilegalnih migranata u Republici Srbiji sa identifikovanim žrtvama trgovine ljudima među tim migrantima, kao posebno ranjive kategorije za trgovinu ljudima, zapaža se da postoji ogromna disproporcija u tim brojevima: 16.500 ilegalnih migranata registrovanih 2014. i samo dve žrtve trgovine ljudima identifikovane među njima $(0,012 \%)$, i 579.518 ilegalnih migranata registrovanih 2015. sa samo devet žrtava trgovine ljudima identifikovanih među njima $(0,0016 \%)$. Komesarijat za žene izbeglice sproveo je istraživanje i objavio izveštaj u kojem se navodi da ženama i devojčicama izbeglicama nisu bile dostupne osnovne usluge $u$ tranzitnim centrima, uključujući seksualnu i reproduktivnu zdravstvenu negu: „Nedostatak jasnih informacija i nedostupnost prevodilaca, naročito žena, sprečilo je žene i devojčice da traže te usluge i upoznaju svoja prava u tom tranzitnom periodu, a zbog generalnog neznanja su postale ranjive za švercere i druge oportuniste koji koriste njihovu nesreću. Ne samo da predstavnici vlade nisu adekvatno opremljeni za identifikovanje i pružanje odgovarajućih usluga za ranjivu populaciju, već su i pokušaji da se uključe preko potrebne usluge negirani. Organizacije građanskog društva sa odgovarajućim rodnim znanjima tipično nisu uključivane tamo gde su najpotrebnije". ${ }^{8}$ Srbija je tranzitna zemlja na balkanskoj ruti i teško je utvrditi da li su žene i devojčice bile podvrgnute nasilju, prevari, eksploataciji, a ako jesu u kojoj meri. Zbog kratkog boravka migranata, odnos poverenja se nije mogao uspostaviti, tako

\footnotetext{
${ }^{8}$ Women Refugee Commission, No Safety for Refugee Women on the European Route: Report from the Balkans, January 2016, accessible at https://www.womensrefugee commission.org/gbn/resources/1265-balkans-2016, (20.4.2019).
} 
da žrtve nisu mogle otvoreno da prenesu svoje iskustvo i zatraže pomoć. Pored kratkog boravka, postoji još mnogo razloga koji otežavaju identifikovanje žrtava. Izbeglice nisu motivisane da se identifikuju kao žrtve i prijave maltretiranje vlastima, što je razumiljvo, jer njihov cilj je da stignu u Evropsku uniju a ne da ostaju duže u Srbiji, ili na putu, kao i da se odvoje od svoje grupe. U razgovoru sa NVO "Grupa 484" one su podelile svoja iskustva sa terena pominjući da pripadnici vladinih agencija, čak i pripadnici bezbednosnih službe (članovi MUP Republike Srbije) koji su prvi u kontaktu sa migrantima i izbeglicama) nisu dovoljno pažljivi i nemaju posebna znanja i obuku za identifikovanje ili rad na identifikovanju žrtava trgovine ljudima. Isto tako, istraživači NVO "Grupa 484" su naveli da je samo jedno sklonište za žrtve trgovine ljudima u funkciji u Republici Srbiji i njega vodi NVO "Atina", kapacitet mu je samo osam lica. Pored toga, timovi na terenu za medicinsku negu nisu zabeležili nikakve povrede koje se mogu pripisati posledicama nasilja. Međutim, aktivisti NVO su zabeležili da su izbeglice pristigle iz Bugarske imale vidljive povrede, modrice, ogrebotine i ožiljke, što je posledica nasilja i mučenja zvaničnih predstavnika Bugarske. U skladu sa Agencijom za izbeglice UN (UNHCR), Uputstvima za međunarodnu zaštitu - primena člana 1a (2) Konvencije iz 1951.godine, i/ili Protokola koji se odnosi na status izbeglica, žrtve trgovine i lica podložna trgovini iz 1967. godine, ${ }^{9}$ kao i direktive EU o sprečavanju i suprotstavljanju trgovini ljudima i o zaštiti žrtava, pomoć treba pružiti ako postoji bilo kakav indikator moguće žrtve trgovine. ${ }^{10}$ Da bi se sprečila sekundarna viktimizacija i nepotrebna patnja žrtava $\mathrm{u}$ istražnom procesu treba izbeći nepotrebne kontakte žrtava i počinilaca. Pružanje usluga i podrška identifikovanim žrtvama ne sme da bude uslovljena saradnjom $u$ istrazi ili sudskom procesu. Komitet za eliminisanje diskriminacije žena tvrdi da ovaj Komitet „naglašava svoju zabrinutost da su žrtve trgovine koje ne sarađuju sa policijom u istrazi i sudskom procesu izuzete od zaštite. Komitet smatra da je nametanjem tih uslova vladi Holandije ozbiljno narušena mogućnost da stigne i pomogne žrtvama trgovine" ${ }^{11}$ Nedostatak preciznih indikatora za identifikovanje žrtava trgovine i šverca, nedovoljna osetljivost i obučenost

\footnotetext{
${ }^{9}$ United Nations Refugee Agency UNHCR, Guidelines on International Protection - The Application of Article 1a(2) of the 1951 Convention and/or 1967 Protocol Relating to the Status of Refugees, to Victims of Trafficking and Persons at Risk of Being Trafficked, April 2006, accessible at www.unhcr.org/publications/legal/443b626b2/guidelines-internationalprotection-7-application-article-102-1951-convention-html, (11.4.2019).

${ }^{10}$ European Union (EU) Directive on Preventing and Combating Trafficking in Human Beings and Protecting its Victims, European Parliament, April 2011, accessible at http://eurlex.europa.eu/LexUriServ.do?uri=OJ:L:2011:101:0001:EN:pdf, (3.8.2019).

${ }^{11}$ CEDAW, Convention on the Elimination of all forms of Discrimination against Women, Concluding Observations Netherlands, February 2010, accessible at www.2.ohchr.org/

112 ENGLISH/bodies/cedaw/docs/co/CEDAW-C-NLD-CO-5.rdf, (25.3.2019).
} 
zaposlenih u vladi koji su prvi u kontaktu sa izbeglicama i migrantima dovodi do nemogućnosti pravovremenog otkrivanja žrtava trgovine ljudima. Nepoštovanje minimalnih standarda zaštite migranata i žrtava trgovine ljudima predstavlja problem koji za posledicu ima veoma mali broj identifikovanih žrtava trgovine kod izbegličke i migrantske populacije.

Trgovina ljudima i šverc su povezani, ali nisu isti. Kao veoma ranjivo stanovništvo ilegalni migranti lako mogu postati žrtve trgovine ljudima. Iz perspektive toga da je $\mathrm{u}$ poslednjih nekoliko godina priliv migranata $\mathrm{i}$ izbeglica u zemlje jugoistočne Evrope veliki, vlada treba da preduzme mere da spreči švercere i pravilno radi sa izbeglicama i migrantima na prepoznavanju mogućih žrtava trgovine ljudima, i da im pruži neophodnu pomoć i zaštitu u skladu sa međunarodnim konvencijama i preporukama. U tom kontekstu potrebno je: 1) razviti i primeniti standarde i procedure pružanja pomoći žrtvama na svim nivoima, od identifikacije do reintegracije i razviti protokole o saradnji između vlade i NVO; 2) obučiti zaposlene u vladi o trgovini ljudima, naročito one koji su prvi u kontaktu sa migrantima i izbeglicama, povećati njihovu osetljivost radi boljeg prepoznavanja žrtava trgovine ljudima; 3) pokušati povećati kapacitete za smeštaj izbeglica i migranata, naročito broj i kapacitet skloništa za moguće žrtve trgovine ljudima, i obezbediti usluge i pomoć za bolje prevazilaženje trauma žrtava.

\section{Sistem borbe protiv trgovine ljudima u zemljama jugoistočne Evrope}

Međunarodni institucionalni okvir za borbu protiv trgovine ljudima ustanovljen je UN Konvencijom za borbu protiv transnacionalnog kriminala i dodatnim protokolima o trgovini ljudima i švercu migranata. Takođe, Konvencija SE za borbu protiv trgovine ljudima, zajedno sa već pomenutim UN instrumentima, čini međunarodni pravni okvir i sistem za borbu protiv trgovine ljudima, jača zaštitu žrtava usredsređujući se na zaštitu ljudskih prava. Sve zemlje članice Saveta Evrope, tj. zemlje jugoistočne Evrope bez Kosova, imaju obavezu da osmisle sistem za borbu protiv trgovine ljudima koji bi mogao da ispuni zahteve i obaveze koje proizilaze iz Konvencije.

Za bolji uvid u rad NVO u Srbiji, ovde smo upotrebili intervju sa Katarinom Ivanović, koordinatorkom za kontakte sa javnošću iz NVO "Astra" u Beogradu. 


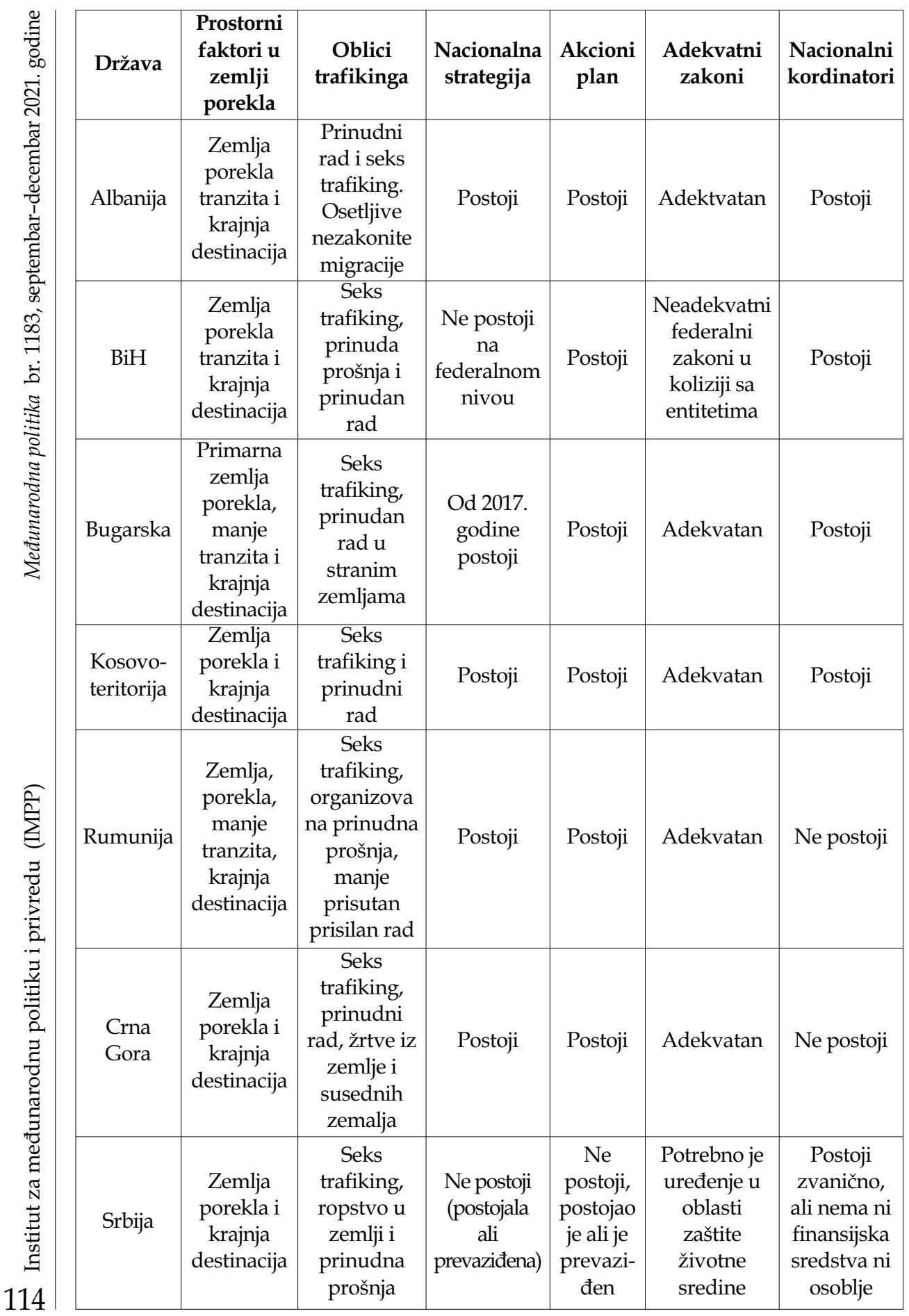


Na osnovu člana 5 Konvencije, svaka država treba da ustanovi koordinaciju na nacionalnom nivou između različitih tela odgovornih za sprečavanje i borbu protiv trgovine ljudima, za kreiranje i sprovođenje efikasne politike, zakona i drugih mera potrebnih da se obezbedi da krivična dela budu definisana u skladu sa Konvencijom. ${ }^{12}$ Takođe, svaka država treba da osmisli programe za sprečavanje trgovine ljudima i da uključi NVO i druge relevantne organizacije civilnog društva u tu borbu, kao i u aktivnosti zaštite žrtava. Konvencija uspostavlja efikasan mehanizam za praćenje sprovođenja Konvencije u zemljama potpisnicama. Da bismo dobili bolji i drugačiji uvid u sistem za borbu protiv trgovine ljudima u zemljama jugoistočne Evrope, analiziraćemo napore i rezultate institucija koje čine ovaj sistem. U donjoj tabeli vidimo zemlje jugoistočne Evrope, primarne oblike trgovine ljudima i pregled osnovne strukture za borbu protiv trgovine ljudima u skladu sa Konvencijom SE.

U cilju primene ove Konvencije, Savet Evrope je formirao kontrolni mehanizam u vidu Grupe stručnjaka za delovanje protiv trgovine ljudima (GRETA) i Komitet potpisnika. Konvencija daje definiciju trgovine ljudima i osnovni sistem koji zahteva nacionalnu koordinaciju raznih organa zaduženih za prevenciju i suzbijanje trgovine ljudima, formiranje i jačanje efikasnih doktrina i programa za sprečavanje trafikinga, ispitivanje i zaštitu žrtava i uključivanje NVO i drugih značajnih organa i organizacija civilnog društva u sistem protiv trgovine ljudima.

To obuhvata mere i sistem za efikasan rad na:

1. Identifikovanju žrtava;

2. Pomoći žrtvama;

3. Pravo na period oporavka;

4. Kompenzaciju i pravnu pomoć žrtvama trafikinga;

5. Repatrijaciju i povratak žrtava;

6. Kriminalizovanje trafikinga u skladu sa Konvencijom;

7. Sankcije i mere za počinioce;

8. Nepostojanje kaznenih odredbi za žrtve trafikinga;

9. Efikasnu istragu i sudski postupak uz zaštitu ljudskih prava žrtve;

10. Specijalne organe i koordinaciona tela;

11. Međunarodnu saradnju i saradnju sa organizacijama građanskog društva.

${ }^{12}$ Council of Europe Convention on Action against Trafficking in Human Beings (CoE Convention, 2005, accessible at https://rm.coe.int/CoERMPublicCommonSearch Services/DisplayDCTMContent, (11.3.2017). 
Zemlje jugoistočne Evrope koje su obrađene u ovom radu imaju sistem za suzbijanje trgovine ljudima. Sve zemlje, osim Kosova, su članice Saveta Evrope i potpisnice Konvencije. Sve imaju mere za borbu protiv trgovine ljudima, ali generalno, sve zemlje treba da učine više na ispunjavanju uslova Konvencije.

1. Albanija treba da preduzme mere na smanjivanju potreba za trgovinom ljudima, na motivisanju policije i drugih nadležnih organa za identifikovanje žrtava prisilnog prosjačenja, posebno dece, rad na suzbijanju sive ekonomije da bi se smanjila trgovina radnom snagom, preduzimanju mera za proaktivno identifikovanje žrtava među migrantima i rad na suzbijanju korupcije funkcionera vlade. ${ }^{13}$

2. BiH treba da ujednače sve zakone (savezne i entiteta) u skladu sa odredbama Konvencije Saveta Evrope, da formira kancelariju koordinatora protiv trafikinga kao stalno zaposlenje i da član 26 Konvencije unesu u svoj zakon (nepostojanje kazni za žrtve trafikinga). ${ }^{14}$

3. Bugarska treba da formira koordinaciono telo $\mathrm{u}$ vidu koordinatora protiv trafikinga, da izdvoji sredstva i budžet za program protiv trafikinga, posebno za prevenciju, zaštitu i zbrinjavanje žrtava, da uključe NVO u nacionalnu politiku i pojačaju aktivnosti na adekvatnoj istrazi, procesuiranju i osudi počinilaca. ${ }^{15}$

4. Kosovo treba da poveća saradnju i partnerstvo sa ostalim zemljama u regionu potpisivanjem bilateralnih sporazuma, da proaktivno radi na identifikovanju žrtava među migrantima i ranjivim grupama (deca, Romi), adekvatno utvrdi problem korupcije i da aktivno radi na suzbijanju korupcije kod funkcionera vlade. ${ }^{16}$

5. Crna Gora treba da ustanovi nacionalnog koordinatora za borbu protiv trgovine ljudima koji bi koordinirao mere za borbu protiv trgovine ljudima i proaktivno radio na identifikovanju žrtava (posebno prisilnog rada), da donese zakone u skladu sa Konvencijom Saveta Evrope i obuči istražitelje i tužioce za rad na slučajevima trgovine ljudima. ${ }^{17}$

${ }^{13}$ Council of Europe, GRETA Report Albania, 2016, accessible at http://www.coe.int/en/ web/anti-human-trafficking/-/publication-of-greta-s-second-report-onalbania, (15.3.2019).

${ }^{14}$ Council of Europe, GRETA Report Bosnia and Herzegovina, 2013, accessible at http:/ / www.coe.int/en/web/anti-human-trafficking/-/greta-s-second-evaluationround-visit-tobosnia-and-herzegovina, (18.3.2019).

${ }^{15}$ Council of Europe, GRETA Report Bulgaria, 2015, accessible at http://www.coe.int/ en/web/anti-human-trafficking/bulgaria, (15.3.2019).

${ }^{16}$ Council of Europe, GRETA Report Kosovo, 2015, accessible at http://www.coe.int/ en/web/anti-human-trafficking/news/-/asset_publisher/fX6ZWufj34JY/content/ publication-of-greta-report-on-kosovo-, (12.2.2019).

${ }^{17}$ Council of Europe, GRETA Report Montenegro, 2016, accessible at http:/ / www.coe.int/ en/web/anti-human-trafficking/-/publication-of-greta-s-second-report-onmontenegro,

116 (1.3.2019). 
6. Rumunija treba da ustanovi nacionalnog koordinatora kao nezavisno telo za koordiniranje aktivnosti na suzbijanju trgovine ljudima, za preduzimanje mera na smanjenju ranjivosti određenih grupa, da proaktivno radi na prevenciji trgovine ljudima da bi se povećao kapacitet za pomoć i zbrinjavanje žrtava, da obuči inspektore za rad i pojača aktivnosti na sprečavanju radne eksploatacije, da poveća sredstva za zbrinjavanje. ${ }^{18}$

7. Srbija treba da ustanovi stalno zaposlenog koordinatora za borbu protiv trgovine ljudima i obezbedi mu zaposlene i sredstva, da usvoji nacionalnu strategiju i akcioni plan za borbu protiv trgovine ljudima, preduzme preventivne mere za smanjenje potreba za trgovinom ljudima, da poveća budžet za finansiranje mera za suzbijanje trgovine ljudima, da obuči policiju koja će proaktivno raditi na identifikovanju žrtava i istragama, da poveća saradnju sa NVO. ${ }^{19}$

Pojačanim naporima i merama za ispunjavanje međunarodnih obaveza prema Konvenciji, situacija trgovine ljudima i zaštite ljudskih prava treba da se poboljša. Svim državama nedostaju sredstva, tako da se finansiranje može obezbediti iz pristupnih sredstava EU uz strogu kontrolu korišćenja. Za sve ove mere zemljama je potrebna politička volja da se prevaziđu tenzije između država i da se snage udruže zbog zajedničkog cilja: mir, stabilnost i bezbednost.

\section{Studija slučaja - Austrija}

Uslovljena složenim geopolitičkim položajem, kao i visokim stepenom društvenog, ekonomskog i kulturološkog razvoja Austrija predstavlja jednu od zemalja Evropske unije koja spada u red najugroženijih iz aspekta migrantske krize. U dosadašnjem toku migrantske krize Austrija je već pretrpela, ali i dalje nastavlja da podnosi ogroman teret $u$ smislu izdvajanja finansijskih i materijalnih sredstava za prihvat, prevoz, smeštaj, ishranu, odevanje, finansiranje i dalju integraciju migranata u svoje društvo. ${ }^{20} \mathrm{Od}$ početka 2015. godine Austrija je primila ogroman broj zahteva za izdavanje azila i proporcijalno prema svojih 8,7 miliona stanovnika, spada u grupu zemalja Evropske unije koje predstavljaju najpoželjnije destinacije za migrante.

${ }^{18}$ Council of Europe, GRETA Report Romania, 2016, accessible at http://www.coe.int/ en/web/anti-human-trafficking/-/council-of-europe-s-anti-traffickingbody-greta-callson-romania-to-intensify-efforts-to-prevent-trafficking-in-children, (5.3.2017).

${ }^{19}$ Council of Europe, GRETA Report Serbia, 2013, accessible at http://www.coe.int /en/web/anti-human-trafficking/-/greta-s-second-evaluation-visit-to-serbia (13.3.2017).

${ }^{20}$ Europol, Operation Golf and Sirocco2, n.d., accessible at www.europol.europa.eu/ activitiesservices/europol-in-action/operations, (10.2.2019). 
Migrantska kriza prouzrokovala je značajno povećanje troškova, kao i dodatno naprezanje državnog aparata Austrije. Javno mnjenje u zemlji svakodnevno je okupirano vestima o prilivu i boravku migranata u Austriji, što kod društva koje je i pre krize bilo opterećeno nagomilanim verskim i nacionalnim pitanjima izaziva oprečne komentare javnosti ali i pozornost građana. Na teritoriji Austrije egzistiraju mnogobrojne vladine i nevladine organizacije i udruženja koja se na različite načine bave pitanjem migranata i ulažu određene napore, ali i materijalna sredstva, kako bi se posledice migrantske krize što bolje prevazišle. Jedna od ovakvih organizacija, osnovana nakon početka krize u Beču, je Savetovalište za migrantkinje i migrante, koje je formirano pod pokroviteljstvom Komiteta za podršku integraciji migranata UKI. Savetovalište predstavlja vanstranačko udruženje od opšteg društvenog interesa čiji je cilj društvena, jezička i profesionalna integracija migranata. Pored kurseva stranih jezika centralni zadatak UKI-a jeste olakšavanje pristupa radu za doseljenike koji su pribavili dozvole za rad u Austriji.

Osnovne deklarisane aktivnosti udruženja su:

- organizovanje kurseva (nemačkog jezika, profesionalne orijentacije, kompjutera itd.);

- završavanje osnovne škole za omladince;

- profesionalna orijentacija i učenje jezika za hendikepirane doseljenike.

Pored ove u Beču, i u čitavoj zemlji, deluju i mnoge druge slične organizacije koje su koncipirane po manje više identičnom modelu. Migranti koji već egzistiraju na teritoriji Austrije predstavljaju poseban bezbednosni rizik za čitavo društvo. Samo tokom 2016. godine zabeleženo je 49 incidenata koje su počinili sami migranti među sobom, u centrima gde su smešteni. Najčešći su bili akti nasilja, ispoljavanje pretnji smrću, različita uznemiravanja i vandalizam. Tokom iste godine registrovan je porast incidenata, koji su bili inicirani od strane desničarskih grupa i pojedinačnih građana a usmereni protiv migranata i centara za njihov prihvat. Tada je zabeleženo veliki broj slučajeva, kao što su ispisivanje grafita ali i bacanje zapaljivih bombi. Statistika ovakvih incidenata beleži trend porasta počev od 2015. godine pa do danas. Među oblicima nasilja koji su ispoljeni prema migrantima zabeleženim u Ministarstvu unutrašnjih poslova bilo je raznih rasističkih grafita, pokušaja izazivanja požara, bacanja kamenja na zgrade, bacanje molotovljevih koktela, uništavanje gasnih cevi i sl.

Bez obzira što austrijske vlasti ulažu velike napore i troše materijalne i ljudske resurse kako bi se na najbolji mogući način izborile sa ovim izazovom, neprestano trpe velike kritike i političke pritiske prvenstveno od strane svog javnog mnjenja i opozicije. Iako su mere koje je Austrija preduzimala povodom migrantske krize uglavnom bile demokratske i u 
skladu sa zvaničnom politikom i konvencijama Evropske unije, primetno je nastojanje svih dosadašnjih vlasti da redefinišu svoju politiku o ovom pitanju, suzbiju priliv migranata i smanje unutrašnje rashode. Opozicija i različita udruženja za zaštitu ljudskih prava veoma vešto koriste ovu situaciju kako bi izvršile dodatni pritisak na vladu i političke lidere. Prema određenim istraživanjima Austrija je od početka migrantske krize pa do sada vratila najmanje nekoliko desetina hiljada migranata sa svoje granice. U poslednje vreme preduzima jače kontrole na graničnim prelazima sa Slovenijom, Hrvatskom i Mađarskom. ${ }^{21}$ Samo iz Slovenije dnevno uđe oko 3.000 migranata u Austriju. Oni koji tvrde da dolaze iz Sirije, Iraka i drugih žarišta na Bliskom istoku bivaju podvrgnuti dodatnim ispitivanjima, a prevodioci proveravaju njihov akcenat kako bi utvrdili da li govore istinu. Sve osobe za koje su posumnjali ili ustanovili da nisu govorile istinu vraćaju nazad. Austrijske vlasti bile su primorane da donose i druge nepopularne mere u pokušaju da prevaziđu krizu. Sebastijan Kurc je još kao ministar spoljnih poslova predlagao smanjenje socijalnih davanja migrantima, uoči opštih izbora 15. oktobra 2017. godine. Prema njegovom planu izbeglicama bi bila smanjena davanja na 560 evra mesečno po osobi, što je oko polovine sume koja se smatra pragom siromaštva prema konsenzusu 40 društvenih grupa, dok bi isplate po domaćinstvu bile ograničene na 1.500 evra.

Polovinom aprila 2018. godine vlada Austrije usvojila je novi set mera u borbi protiv migrantske krize koje podrazumevaju da će svaki migrant morati da preda svoj "pametni” telefon i 840 evra. Pomenuta suma pokrivaće troškove njihovog zahteva za izdavanje azila a vlasti nameravaju da koriste podatke iz njihovih telefona da bi utvrdili način na koji su došli u Austriju. Ukoliko se utvrdi da su ranije ušli u neku evropsku zemlju, mogli mi da budu vraćeni nazad u nju. Ministar unutrašnjih poslova Herbert Kickl, rekao je da su mere uvedene kako bi se „sprečile zloupotrebe”, a o njima uskoro treba da se izjasni austrijski parlament. Austrija je dobila više od 150.000 zahteva za azil.22 Prema novim merama državljanstvo će migranti moći da traže tek za deset godina, a deportacije će biti ubrzane. Ova, kao i većina ranijih mera izazvala je reakciju i negativne komentare aktivista za ljudska prava, koji su upozorili da su nove mere represivne, kao i da krše prava izbeglica. Potpuno je jasno da migrantska kriza proizvodi negativne političke i materijalne implikacije po Austriju i dovodi je u osetljivu bezbednosnu situaciju, naročito ukoliko imamo u vidu islamski

${ }^{21}$ Balkan Insight, Albania Fears Joining New Refugee Route, 2016.accessible at http:// www.balkaninsight.com/en/article/albania-facing-flow-of-refugees-as-transitcountry09-30-2016, (1.4.2019).

${ }^{22}$ Council of Europe, GRETA Report Bosnia and Herzegovina, 2013, accessible at http:/ / www.coe.int/en/web/anti-human-trafficking/-/greta-s-second-evaluationround-visit-tobosnia-and-herzegovina, (18.3.2017). 
faktor, jedan od bezbednosnih rizika sa kojim se Austrija suočava već duži vremenski period, ali i činjenicu da nekontrolisani priliv migranata na njenu teritoriju predstavlja poseban bezbednosni rizik. Potpuno je jasno da je dijapazon radnji i mera koje austrijski državni aparat preduzima izuzetno širok i da obuhvata mere zvanične spoljne i unutrašnje politike, kao i posebne zadatke koje realizuju njihove obaveštajno-bezbednosne strukture. Austrija u dosadašnjem toku migrantske krize nije upotrebljavala vojne, ali je zato angažovala policijske snage u velikom obimu. Njihova policija $u$ saradnji sa graničnom službom i kontraobaveštajnim službama ulaže velike napore, prvenstveno na identifikovanju bivših boraca ISIS, ISIL i DAEŠ koji pristižu pomešani sa izbeglicama iz ratom zahvaćenih područja. Austrijske obaveštajne strukture nastoje da deluju preventivno i da registruju bezbednosno indikativna lica još pre ulaska na teritoriju Austrije, prikupljanjem obaveštajnih podataka na terenu i razmenom obaveštajnih informacija sa stranim službama. Registrovanje potencijalnih nosilaca ekstremističke i terorističke delatnosti predstavlja osnovni zadatak njihovih bezbednosno-obaveštajnih struktura, a sve je podređeno osnovnom zadatku predupređenja potencijalnih terorističkih napada. Operativni podaci koriste se za izradu kvalitetnih bezbednosnih procena sa kojima se upoznaje državno rukovodstvo, a pojedina selektovana lica angažuju se i kao deo njihove saradničke infrastrukture.

Područje jugoistočnog Balkana predstavlja sektor naročite pažnje obaveštajnih struktura Austrije. Obaveštajna i agenturna delatnost njihovih službi veoma je ispoljena na teritoriji Republike Srbije, gde od početka migrantske krize intenzivno prikupljaju obaveštajna saznanja o migranskim rutama i drugim operativnim podacima. Sasvim je izvesno da su na ovim zadacima angažovane gotovo sve vojne i civilne obaveštajne službe, diplomatski elementi sa svojim obaveštajnim kapacitetima (ambasade sa svojim vojnim odeljenjima), kao i obaveštajne strukture ugrađene $u$ međunarodne snage (KFOR, UMNIK i sl.), sa osnovnom idejom preventivnog delovanja i nastojanjem da se prikupi što je moguće više obaveštajnih saznanja i pre nego što migranstke grupe uopšte kroče na teritoriju Austrije.

\section{Studija slučaja - Mađarska}

Tokom trajanja migrantske krize Mađarska je imala značajnu ulogu. Vlada Mađarske se odlučno suprotstavljala pokušajima institucija Evropske unije da uspostavi sistem kvota kao moguć način rešenja migrantske krize. ${ }^{23}$

${ }^{23}$ Dragan Petrović, Rajko Bukvić, Evropa i Migrantsko pitanje 2014-2020, Institut za 120 međunarodnu politiku i privredu, 2020, str. 89. 
Slično kao i Austrija i Mađarska se nalazi na osetljivom geopolitičkom položaju i samim time što je članica Evropske unije predstavlja metu za mnoge migrante. I ona je pretrpela i još uvek podnosi veliko opterećenje zbog migrantske krize, čije posledice i te kako oseća i pokušava da ih otkloni. Tokom nekoliko godina trajanja migrantske krize Mađarska se suočila sa izdvajanjem ogromnih finansijskih sredstava, povećanim angažovanjem državnih subjekata, unutrašnjim i spoljnim političkim pritiscima i drugim mnogobrojnim problemima. Za razliku od Austrije, Mađarska nije najpoželjnija krajnja destinacija kojoj migranti na svom putu streme i ta činjenica im u celoj situaciji ide u prilog. Međutim, Mađarska svakako predstavlja veoma značajno područje na migrantskim rutama, naročito ukoliko u obzir uzmemo činjenicu da prelaskom mađarske granice migranti ostvaruju svoj primarni cilj a to je ulazak na teritoriju Evropske unije. Mađarske vlasti, na čelu sa premijerom Viktorom Orbanom, još na početku krize zauzele su izuzetno čvrst i nepopustljiv stav prema pitanju migranata. Premijer Orban je veliki protivnik i kritičar migracije. On prilično otvoreno govori o negativnim implikacijama migracione krize i upozorava na bezbednosne aspekte nekontrolisanog priliva migranata muslimanske veroispovesti u države Evropske unije, čime izaziva pažnju ali i osudu jednog dela javnosti koja je zaokupljena zaštitom ljudskih prava. Mere koje je mađarska vlada donosila radi konsolidovanja stanja i suprotstavljanja posledicama migrantske krize pokazuju da Orbanove reči nisu izgovorene samo u cilju sticanja unutrašnje političke podrške, i njihove mere su bile daleko rigoroznije $u$ odnosu na mere koje su preduzimale većina ostalih država Evropske unije, naročito iz aspekta poštovanja ljudskih prava i međunarodnih konvencija. Stiče se utisak da je Mađarska, od svih zemalja pogođenih migrantskom krizom, možda i najozbiljnije pristupila rešavanju ovog problema, što svakako može imati veze sa njenim geografskim položajem koji ih pozicionira na balkanski obod Evropske unije i samim time svrstava u grupu potencijalno najugroženijih zemalja Evropske unije iz pravca "Balkanske rute”.

Pored policije Mađari su na rešavanju pitanja migranata angažovali i vojne snage. Rešavanje ovog problema takođe je primoralo vojni i državni vrh da donese odluku o povlačenju dela njihovih vojnih snaga koje su bile angažovanje u okviru treće misije vojske (učešće u mirovnim operacijama u svetu), kako bi bile upotrebljene na suprotstavljanju migrantskoj krizi u zemlji, što su procenili kao državni prioritet u odnosu na mirovne misije. Mađarska je krajem 2015. godine postavila zaštitno tehničku ogradu duž svojih južnih granica. Osnovna ideja kojom su se vodili prilikom realizacije ove kapitalne investicije bila je pokušaj delimičnog zaustavljanja i pre svega kontrole daljeg kretanja migranata iz pravca "Balkanske rute”, kao i smanjenje angažovanja vojnih i policijskih snaga, što im je crpelo značajne 
materijalne ali i ljudske resurse. ${ }^{24}$ Ovakva mera u borbi protiv migracione krize prvi put je implementirana od strane neke od zemalja Evropske unije i odmah je izazvala brojne kritike i osude, prvenstveno strane demokratske javnosti. Međutim, u praksi se ova mera pokazala kao efikasna, pa je ovakav model za kontrolu državne granice pod naletom izbeglica kasnije bio prihvaćen i razmatran kao moguć i od strane drugih zemalja koje su tragale za modelima za rešavanje problema. Koliko ozbiljno su se mađarske vojne snage bavile ovim problemom najbolje pokazuje sastanak između generala Ljubiše Dikovića, načelnika generalštaba Vojske Srbije i generala Tibora Benkea načelnika generalštaba Mađarske vojske, koji je bio realizovan dana 14.6.2016. godine $u$ Segedinu, na inicijativu mađarskih oružanih snaga. ${ }^{25}$ Ključna tema razgovora dvojice načelnika bila je migrantska kriza i razmatranje zajedničkih mogućnosti za delovanje u cilju smanjivanja posledica krize. Tokom sastanka načelnik generalštaba Mađarske vojske izneo je podatak da je Mađarska ugrožena upadima migaranata, prvenstveno na svojim granicama sa R. Srbijom i R. Hrvatskom u dužini od oko 300 kilometara, što iziskuje svakodnevno angažovanje oko 6.100 njihovih vojnika. Ovaj vanplanski zadatak troši mađarskoj vojsci značajan deo budžeta, što koči planiranu modernizaciju i razvoj. Pored ovog javlja se i problem zamora ljudstva, kao i smanjenje rezervi sredstava kojima njihova vojska raspolaže. Mere tehničke zaštite, uglavnom žica, postavljene su pedeset kilometara od graničnih prelaza, ali postoji nezanemarljiv deo granice koji nije pokriven na ovaj način, što stvara dodatne probleme prilikom ilegalnih prelazaka. Procena Generalštaba Mađarske vojske tada je bila da će se „Balkanska ruta”, kojom se migranti kreću prema Zapadnoj Evropi, tokom 2016. godine dislocirati na teritoriju Rumunije, odakle će izbeglice, preko Mađarske, nastojati da se domognu Nemačke. Migranti će u Rumuniju dolaziti iz Turske morskim putem, a Mađarskoj će problem predstavljati dužina granice sa Rumunijom koja iznosi 482 kilometra i za koju trenutno nemaju adekvatno obezbeđenje.

Početkom 2017. godine započeto je sa izgradnjom druge zaštitnotehničke ograde na granici sa R. Srbijom, koja je okončana već polovinom iste godine. Ovaj kompleks zaštitno-tehničke ograde dugačak je 155 kilometara, visok tri metra i prema procenama stručnjaka sposoban je da zaustavi veliku masu ljudi. ${ }^{26}$ Pored ovih mera, tokom iste godine mađarske

\footnotetext{
${ }^{24}$ Independent, Balkan Route map, 2015 - 6 charts and a map that show where Europe's refugee are coming from and and the perilous jurneys they are taking, accessible at www.independent.co.uk/news/world/europe/refugee-crisis-six-charts-that-showwhererefugees-are-comming-from-where-are-going-and-how-they-10482415.html, (10. 4.2017).

${ }^{25}$ Milosav Simović, Kopnena zona bezbednosti, Medija centar Odbrana, Beograd, 2017, str. 321. 
vlasti su u okviru taktike suprotstavljanja migrantskoj krizi primenjivale kampanju vraćanja migranata sa svoje na teritoriju R. Srbije, čime su Srbiju stavile $u$ nezavidan položaj i doveli je $u$ situaciju da praktično postane tampon zona. Mađari su kontinuirano, svakodnevno, noću i preko dana, potpuno ilegalno "gurali" migrante nazad na teritoriju R. Srbije, bez ikakve prethodne najave ili koordinacije sa srpskim vlastima. Poznat je primer bračnog para iz Sirije koji je dobio azil u Austriji, i koji je putujući autobusom na odmor, izveden iz autobusa, oduzeta su mu sva dokumenta i zatim su prebačeni iz Mađarske $u$ R. Srbiju. ${ }^{27}$ Prebacivanje izbeglica na teritoriju Srbije najčešće se vrši u blizini Kelebije i Horgoša, otvaranjem vrata na ogradi i fizičkim guranjem izbeglica nazad. Komesarijat za izbeglice i migracije Republike Srbije ispoljio je ovim povodom veliko negodovanje i ocenio da vraćanje migranata iz susednih država na ovaj način, predstavlja najgrublje kršenje njihovih prava zagarantovanih međunarodnim propisima. Ovakve reakcije međunarodne i domaće javnosti nisu ni najmanje poremetile planove mađarskih vlasti da i dalje nastave sa pooštravanjem mera u procesu prevazilaženja posledica migrantske krize. Početkom 2018. godine vlada Mađarske najavila je novi set zakona o oporezivanju i mogućem kažnjavanju mađarskih organizacija koje pomažu ilegalnim migrantima, a finasiraju se iz inostranstva. Te grupe će morati da se registruju u sudovima i, ukoliko više od polovine sredstava dobijaju iz inostranstva moraće da plate 25 odsto poreza na ta inostrana sredstva. Grupe koje se ne budu registrovale, a za koje vlasti budu smatrale da pomažu ilegalne migracije, biće novčano kažnjene. Zakon bi mogao da bude primenjen i na pojedince za koje država smatra da "organizuju ilegalnu migraciju”, tako što bi im bilo zabranjeno da granicama prilaze na manje od osam kilometara. To bi se odnosilo i na mađarske granice sa R. Srbijom i Ukrajinom. Strancima za koje se proceni da pomažu ilegalnoj migraciji, mogao bi da bude zabranjen ulazak u Mađarsku. Nevladine organizacije i grupe u Mađarskoj za koje se sumnja da imaju veze s ilegalnom migracijom, takođe će morati da poštuju zakon i stave na uvid svoje aktivnosti vlastima. Set novih zakona ne bi se primenjivao na verske i humanitarne organizacije, kao što su Crveni krst i druge koje dele hranu, lekove i pružaju drugu vrstu pomoći najugroženijim migrantima. Mađarska javnost je ovaj set zakona kolokvijalno nazvala „Stop Sorošu", jer mediji u Mađarskoj veoma često okrivljuje milijardera i filantropa Džordža Soroša zbog migracija u Evropi, delom jer finansira grupe koje brane prava izbeglica. ${ }^{28}$ Naime, „Helsinški komitet Mađarske”,

\footnotetext{
${ }^{27}$ Norwegian Ministry of foreign affairs, Report on Serbia in Chapters 23 and 24, Belgrade 2016, accessible at http:// preugovor.org/Reports/1321/Coalition-prEUgovor-ReportonProgress-of-Serbia.shtml (10.3.2017).

${ }^{28}$ Nederland's Helsinki Committee, n.d., accessible at www.nhc.nl/cms_file.php?fromDB= 395\&forceDownload, (10.3.2017).
} 
grupa za prava koja pruža pomoć tražiocima azila i delom se finansira iz Soroševe fondacije "Otvoreno društvo”, uporedila je odredbu vlade o neprilaženju granici na manje od osam kilometara, sa uredbom komunističke vlasti Mađarske iz 1969. godine o zabrani građanima da se graničnoj liniji približi na manje od dva kilometra.

Početkom maja 2018. godine vlada Mađarske odlučno je odbila potpisivanje još jedne u nizu konvencija kojima se reguliše odnos država Evropske unije prema migrantima uz ocenu da je u pitanju ,promigrantska” konvencija. Možemo zaključiti da je Mađarska, u odnosu na Austriju, možda otišla i korak dalje u primeni različitih mera za prevazilaženje migranstke krize. Pored obimnog angažovanja vojnih i policijskih snaga, preduzimanja različitih mera, donošenja zakonskih odredbi o ovom pitanju, u procesu prevazilaženja migrantske krize Mađarska se prilično oslanja i na primenu tehničkih mera. Ogromnu količinu novčanih sredstava uložili su u izgradnju zaštitne ograde i postavljanje tehničkih sredstava za kontrolu kretanja migranata. Odluka o izgradnji zaštitno tehničke ograde doneta je na osnovu ozbiljne bezbednosne procene ali i ekonomskih analiza prema kojima njihove vojne i policijske snage nisu u stanju da, pored redovnih zadataka, odgovore bezbednosnim rizicima i pretnjama izazvanim migrantskom krizom. Obaveštajno-bezbednosne strukture Mađarske bave se prikupljanjem obaveštajnih podataka o migrantima, iako nisu toliko efikasne kao što je to slučaj sa austrijskim ili hrvatskim službama. U obaveštajnim i bezbednosnih krugovima vlada mišljenje da su mađarske tajne službe tradicionalno opredeljne za korišćenje tehničkih sredstava $u$ odnosu na ljudski faktor, pa s tim u vezi više se oslanjaju i primenjuju tehnička sredstva i za prikupljanju podataka o kretanjima i aktivnostima migranata. Tokom 2017. i 2018. godine Vojska Srbije je u više navrata registrovala povredu vazdušnog prostora na teritoriji Vojvodine, koji su najverovatnije bili prouzrokovani nadletanjem mađarskih helihoptera, najverovatnije iz njihove avio-baze u Kečkemetu. Pored nadletanja helihoptera registrovano je izviđanje teritorije Banata putem izviđačkog drona, za koji se takođe spekuliše da su ga koristile mađarske granične snage. Procena bezbednosnih struktura R. Srbije ukazuje na to da se najverovatnije radi o pokušaju oružanih snaga Mađarske da osmatranjem iz vazduha prikupljaju operativne podatke o kretanju migranata.

\section{Zaključak}

Migrantska kriza u ovakvom obimu nije zabeležena u poznatoj istoriji čovečanstva, još od velikih migracija stanovništva iz Evrope i Azije u Severnu Ameriku tokom XVIII i XIX veka, i kao takva predstavlja svojevrsni društveni fenomen koji će svakako obeležiti početak a možda i čitav XXI 
vek. Ne treba zaboraviti da velike migracije stanovništva, koje se uglavnom odvijaju iz Afrike, dalekoistočnih i bliskoistočnih zemalja preko Sredozemlja i Balkana, prema razvijenim zemljama zapadne Evrope i dalje traju, te da njihove krajnje posledice još uvek nije moguće u potpunosti sagledati. Još uoči početka migrantske krize postojale su određene procene i pokazatelji koji su na nju ukazivali. U evropskoj strategiji bezbednosti migracije iz Severne Afrike i sa Bliskog istoka prepoznate su kao bezbednosni izazov XXI veka, međutim procena je bila da će do njih doći zbog naglog smanjenja životnih resursa i to najviše usled nestašice vode, a ne i da će talas migracija biti pokrenut zbog izbijanja ratnih dejstava na ovom području.

Migrantska kriza pogodila je čitavu Evropu i svet, ali svakako da su najveći njen teret podnele najrazvijenije zemlje Evropske unije. Slabije razvijene balkanske države nastavile su da „,igraju" ulogu koju im je istorija davno nametnula, a to je da budu raskrsnica važnih puteva i tranzitno područje preko koga je prešao najveći broj izbeglica na svom putu ka zapadnoj Evropi. I pored toga što je teret krize bio nesrazmeran, kao i činjenice da su razvijene evropske države bile glavna meta migranata, posledice koje je ona ostavila na slabije razvijene tranzitne zemlje, za sada su možda čak i teže. Iako ne možemo sa sigurnošću da tvrdimo koje su države i u kom obimu raspolagale sa pravovremenim obaveštajnim podacima o nadolazećim migracijama, svakako možemo reći da je veliki deo njih doživeo iznenađenje, čime su bile dovedene $u$ nepovoljnu situaciju a potencijal $u$ primeni mera sveden im je samo na primenu onih mera koje podrazumevaju otklanjanje posledica. Zajedničko za sve tri države koje smo razmatrali kroz studiju slučaja jeste da se radi o zemljama Evropske unije, iako su apsolutno neravnopravne iz aspekta svojih ekonomskih a samim time vojnih, pa i političkih potencijala. Za razliku od Mađarske, Austrija predstavlja jednu od poželjnih krajnjih destinacija za traženje azila od strane izbeglica i samim time može se reći da je $u$ odnosu na druge dve navedene države podnela veći teret migrantske krize. Nijhovo društvo na većem je stepenu kulturološkog razvoja, što je uticalo da mere koje Austrija preduzima prema migrantima budu manje rigidne a više humane. S druge strane, Mađarska se odlučila da primenjuje strategiju odvraćanja izbeglica od svoje teritorije, što nije potpuno u skladu sa evropskim i etičkim vrednostima ali je svakako dalo određene rezultate. Kao što je već navedeno, najverovatnije da su obaveštajne strukture Austrije i Mađarske raspolagale određenim podacima o pojavi krize, ali sudeći na osnovu kasnijih mera u suprotstavljanju krizi, koje su uglavnom bile represivnog a ne i preventivnog karaktera, najverovatnije da ovaj izazov nisu shvatile dovoljno ozbiljnim.

Sve tri države primenjivale su relativno slične mere u cilju saniranja posledica migrantske krize, s tim što je Mađarska jedina izgradila zaštitnotehničku ogradu radi kontrole kretanja migrantskih grupa. Mađarska je 
ujedno prednjačila $u$ korišćenju tehničkih sredstava za prikupljanje obaveštajnih podataka o izbeglicama, dok se Austrija u tome uglavnom oslanjala na svoje obaveštajne kapacitete. Važno je napomenuti da su sve tri države imale unutrašnju reakciju od strane aktivista iz različitih udruženja za borbu za ljudska prava, što je svakako za njih predstavljalo ograničavajući faktor u borbi protiv migrantske krize. Teško je dati univerzalan ili jednostavan odgovor na pitanje: Kako se boriti protiv migrantske krize? Odgovor na ovo pitanje zahteva kompleksno naučno istraživanje $\mathrm{i}$ angažovanje svih relevantnih, a pre svega bezbednosnih struktura konkretne države. Svakako da obaveštajno angažovanje u cilju prikupljanja pravovremenih i sveobuhvatnih podataka o migrantima predstavlja osnov za izradu kvalitetne bezbednosne i kontraobaveštajne procene, a samim time i za pronalaženje optimalnog rešenja. Rešenje samo po sebi mora biti kompleksno i treba da predstavlja čitav konglomerat radnji, mera i postupka čitavog državnog aparata. Naravno da svaka od pogođenih država treba da prilagođava mere svojim konkretnim interesima, vodeći pri tome računa o međunarodnim konvencijama, ljudskim pravima i pre svega etičkim načelima. Iz svega navedenog nije teško zaljučiti da bi koordinirano, preventivno, međunarodno delovanje uoči početka migracija dalo daleko bolje rezultate nego represivno, koje se sprovodi trenutno. Međutim, postavlja se pitanje da li je neki od svetskih centara moći možda imao motiv da inicira migraciju, što preventivni vid delovanja svodi na relativno ograničen krug mera, koje bi preduzimale uglavnom pojedinačne države.

Ozbiljni geopolitičari i ljudi koji raspolažu obaveštajnim informacijama navode i pozitivne aspekte migracija, koje su prema određenim procenama namerno izazvane od strane privredne osovine Berlin-Pariz-London. Postoje saznanja koja ukazuju da je režim Bašara El Asada u Siriji delimično rušen s ciljem pokretanja talasa migracija. Pored toga "zapadnim" novcem je de facto finasirana izgradnja i funkcionisanje izbegličkih kampova u Turskoj, kako bi priliv migranata u Evropu bio koliko-toliko kontrolisan. Najveći deo visoko i srednje kvalifikovane radne snage, koja je došla u Evropu u početnim talasima migracije, dobio je azil u zapadnoevropskim zemljama, što se ujedno poklopilo sa njihovom potrebom za relativno jeftinom a pri tome kvalifikovanom radnom snagom. $S$ tim u vezi možemo navesti da ovaj rad daje dobru polaznu osnovu za dalje širenje problematike i traženje optimalnih rešenja u borbi protiv migranstke krize. Neki od problema koje smo inicirali možda postanu deo naučnih istraživanja $u$ narednom periodu. 


\section{Literatura}

Mishra, Veerendra, Combating Human Trafficking Gaps in Policy and Law, Sage publications, New York, 2015.

Petrović, Dragan, Bukvić, Rajko, Evropa i migtantsko pitanje 2014-2020, Institut za međunarodnu politiku i privredu, Beograd, 2020.

Simović, Milosav, Kopnena zona bezbednosti, Medija centar Odbrana, Beograd, 2017.

Independent, Balkan Route map, 2015 - 6 charts and a map that show where Europe's refugee are coming from and and the perilous jurneys they are taking, accessible at www.independent.co.uk/news/world/europe/ refugee-crisis-six-charts-that-show-whererefugees -are-comming-fromwhere-are-going-and-how-they-10482415.html, (10.4.2017).

United Nations Protocol against Smuggling of Migrants by Land, See and Air, 2000, accessible at https:/ / www.unodc.org/documents/southeast asiaandpacific/2011/04/somindonesia/convention_smug_eng.pdf, (15.2.2017).

Criminal code of Republic of Serbia, 2017, accessible at www.mpravde. gov.rs/files/CRIMINAL\%20CODE\%20SERBIA.doc, (20.04.2017)

Women Refugee Commission, No Safety for Refugee Women on the European Route: Report from the Balkans, January 2016, accessible at https://www.womensrefugeecommission.org/gbn/resources/1265balkans-2016, (20.4.2017).

United Nations Refugee Agency UNHCR, Guidelines on International Protection - The Application of Article 1a(2) of the 1951 Convention and/or 1967 Protocol Relating to the Status of Refugees, to Victims of Trafficking and Persons at Risk of Being Trafficked, April 2006, accessible at www.unhcr.org/publications/legal/443b626b2/guidelines-internationalprotection-7-application-article-102-1951-conventionhtml, (11.4.2017).

European Union (EU) Directive on Preventing and Combating Trafficking in Human Beings and Protecting its Victims, European Parliament, April 2011, accessible at http://eurlex.europa.eu/LexUriServ.do?uri=OJ:L: 2011:101:0001:EN:pdf, (3.4.2017).

Council of Europe Convention on Action against Trafficking in Human Beings (CoE Convention, 2005, accessible at https:/ / rm.coe.int/CoERM PublicCommonSearchServices/DisplayDCTMContent?, (11.03.2017).

Council of Europe, GRETA Report Albania, 2016, accessible at http://www.coe.int/en/web/anti-human-trafficking/-/publicationof-greta-s-second-report-onalbania, (15.3.2017). 
Balkan Insight, Albania Fears Joining New Refugee Route, 2016.accessible at http://www.balkaninsight.com/en/article/albania-facing-flow-ofrefugees-as-transit-country09-30-2016, (1.4.2017).

Council of Europe, GRETA Report Bosnia and Herzegovina, 2013, accessible at http://www.coe.int/en/web/anti-human-trafficking/-/greta-ssecond-evaluation-round-visit-tobosnia-and-herzegovina, (18.3.2017).

Ministry of security of Bosnia and Herzegovina, Strategy to Counter Trafficking in Human Beings in Bosnia and Herzegovina and Action Plan, 2013, accessible at http://www.msb.gov.ba/dokumenti/ strateski/ default.aspx?id=9092\&langTag=en-US, (24.4.2017).

Council of Europe, GRETA Report Bulgaria, 2015, accessible at http:// www.coe.int/en/web/anti-human-trafficking/bulgaria, (15.3.2017).

Council of Europe, GRETA Report Kosovo, 2015, accessible at http:// www.coe.int/en/web/anti-human-trafficking/news/-/asset_ publisher/fX6ZWufj34JY/content/ publication-of-greta-report-onkosovo-, (12.2.2017).

Council of Europe, GRETA Report Montenegro, 2016, accessible at http:/ / www.coe.int/en/web/anti-human-trafficking/-/ publicationof-greta-s-second-report-onmontenegro, (1.3.2017).

Council of Europe, GRETA Report Romania, 2016, accessible at http://www.coe.int/en/web/anti-human-trafficking/-/council-ofeurope-s-anti-traffickingbody-greta-calls-on-romania-to-intensifyefforts-to-prevent-trafficking-in-children, (5.3.2017).

Nederland's Helsinki Committee, n.d., accessible at www.nhc.nl/ cms_file.php?fromDB=395\&forceDownload, (10.3.2017).

Council of Europe, GRETA Report Serbia, 2013, accessible at http:// www.coe.int/en/web/anti-human-trafficking/-/greta-s-secondevaluation-visit-to-serbia (13.3.2017).

Norwegian Ministry of foreign affairs, Report on Serbia in Chapters 23 and 24, Belgrade 2016, accessible at http://preugovor.org/Reports/ 1321/Coalition-prEUgovor-Report-onProgress-of-Serbia.shtml. (10.3.2017).

Ministry of Internal Affairs Program of Professional Development and Training of police Employees for the Year of 2017. (MUP Republike Srbije, Beograd, 2017) Transparency International, Corruption perception index, 2016, accessible at http:/ /www.transparency.org/ news/feature/corruption_perceptions_index_2016, (22.4.2017).

Europol, Operation Golf and Sirocco2, n.d., accessible at www.europol. europa.eu/activitiesservices/europol-in-action/operations, (10.2.2017). 


\section{THE MIGRANT CRISIS, ILLEGAL MIGRATION, AND HUMAN TRAFFICKING AS SECURITY PROBLEMS: A CASE STUDY OF AUSTRIA AND HUNGARY}

\section{ABSTRACT}

Migrations instigated by war and suffering, the actions of radical Islamists and the formation of the Islamic State on the territory of several Middle Eastern countries forced European states to act systematically against the invasion of migrants over a long period, spending their resources and overworking their police, military and civilian capabilities. Through the topic "Illegal migration and security responses, a case study on the example of Austria and Hungary," we will attempt to comprehend modern illegal migration. We examined the work and outcomes of Southeast European anti-trafficking and anti-trafficking systems, including governmental and non-governmental organizations and their responsibilities in the system, to determine which capacities have yet to be developed and where the systems' weaknesses lie.

Keywords: Illegal migration, human trafficking, Europe, Austria, Hungary. 